
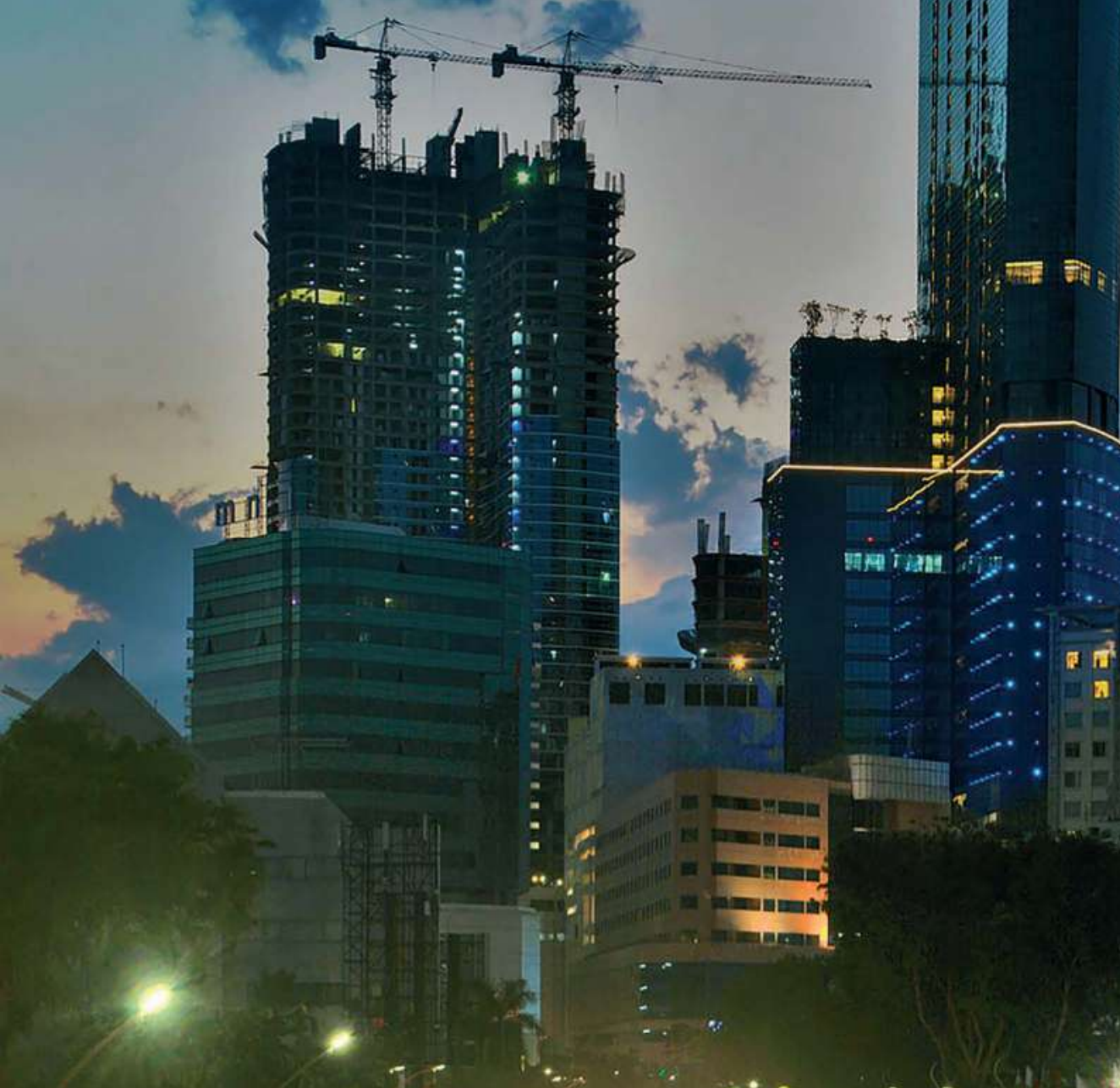

\section{Editors}

Badri Munir Sukoco

Rahmat Heru Setianto Nidya Ayu Arina Ade Gafar Abdullah Asep Bayu Nandiyanto Ratih Hurriyati

\section{Increasing Management Relevance \\ and}

\section{CPD \\ CERTIFIED

(ci. C) CRC Press

A BALKEMA BOOK 
PROCEEDINGS OF THE $2^{\text {ND }}$ GLOBAL CONFERENCE ON BUSINESS, MANAGEMENT AND ENTREPRENEURSHIP (GC-BME 2017), AUGUST 9, 2017, UNIVERSITAS AIRLANGGA, SURABAYA, INDONESIA

\section{Increasing Management Relevance and Competitiveness}

Editors

Badri Munir Sukoco, Rahmat Heru Setianto \& Nidya Ayu Arina Universitas Airlangga, Indonesia

Ade Gafar Abdullah, Asep Bayu Nandiyanto \& Ratih Hurriyati Universitas Pendidikan, Indonesia

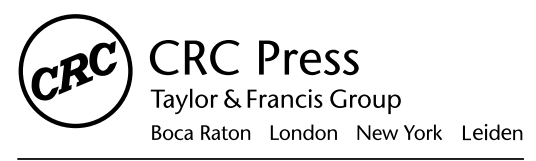

CRC Press is an imprint of the

Taylor \& Francis Group, an informa business

A BALKEMA BOOK 
CRC Press/Balkema is an imprint of the Taylor \& Francis Group, an informa business

(C) 2018 Taylor \& Francis Group, London, UK

Typeset by V Publishing Solutions Pvt Ltd., Chennai, India Printed and bound in Great Britain by CPI Group (UK) Ltd, Croydon, CR0 4YY

All rights reserved. No part of this publication or the information contained herein may be reproduced, stored in a retrieval system, or transmitted in any form or by any means, electronic, mechanical, by photocopying, recording or otherwise, without written prior permission from the publisher.

Although all care is taken to ensure integrity and the quality of this publication and the information herein, no responsibility is assumed by the publishers nor the author for any damage to the property or persons as a result of operation or use of this publication and/or the information contained herein.

Published by: CRC Press/Balkema

Schipholweg 107C, 2316 XC Leiden, The Netherlands

e-mail: Pub.NL@taylorandfrancis.com

www.crcpress.com - www.taylorandfrancis.com

ISBN: 978-0-8153-7455-8 (Hbk)

ISBN: 978-1-351-24189-2 (eBook) 


\section{Table of contents}

Preface $\quad$ xi

$\begin{array}{lc}\text { Acknowledgements } & \text { xiii }\end{array}$

$\begin{array}{ll}\text { Organizing committees } & \mathrm{XV}\end{array}$

Strategic management, entrepreneurship and contemporary issues

Governance of financial intangible success factors: An option in building business resilience and sustainability

P. Sugito

The influences of the alliance learning process and entrepreneurial orientation on the strategic alliance performance of Indonesian construction companies R. Handayani \& R. Dyah Kusumastuti

Assessing necessity and opportunity-based entrepreneurship: An analysis of demographic characteristics, propensity for new ventures and entrepreneurial motivation (a study of labor forces and entrepreneurs in Padang, Indonesia)

H. Rahman \& D. Lesmana

Critical assessment on zakat management: Zakat scorecard model

T. Widiastuti, S. Herianingrum \& I. Mawardi

Investigating entrepreneurial orientation impact on project performance in highly regulated industry: A case of renewable power industry in Indonesia

F.A. Firman, R.D. Kusumastuti, H.T. Kurniawan \& I.M. Ruky

How to survive in the modern era: Integrated local entrepreneurs, the traditional market and the modern store

P.P.D. Astuti, Y. Setyowati \& A.A.G.S. Utama

xi iii

XV

The influence of Islamic service quality toward bank customer loyalty and satisfaction of

BRISyariah Surabaya

M.Q. Fauzi, S. Herianingrum, T. Widiastuti \& R. P. Putra

Management accounting practices in micro enterprises in the Sleman Regency, Daerah

Istimewa Yogyakarta

A.C. Laksmi \& A.P. Putra

The power of finance: The dynamics of female entrepreneurs in fulfilling their financial needs

M.R. Rita, S. Wahyudi \& H. Muharam

Entrepreneurial orientation in a family business group: The role of the corporate center and its effect on business unit performance

O. Pendrian, K.A. Karnen, R. Rachmawati \& R.D. Kusumastuti

Developing entrepreneurship for the performing arts community through an art incubation model

J. Masunah \& R. Milyartini

Capability to contest on market performance

61

B. M. Sukoco \& R. R. Maulana 
The influence of the socio-economic status of parents toward entrepreneurial attitudes H. Mulyadi, M. Arief Ramdhany \& S. Sulastri

Analysis of the factors affecting the elected mode of transportation for workers using an analytical hierarchy process

E. Mahpudin \& H. Sulistiyo

71

75

Multidimensional approach for assessing service quality in the service industry

Y.D. Lestari

The influence of entrepreneurship orientation and management capability on performance of small and medium enterprises in Bogor

A. Setyo Pranowo, H. Hari Mulyadi, Z. Musannip Efendi Siregar \&

Y. Hendayana

The influence of family factors on expatriate performance

N. Kartika

Is firm size an important determinant for firms in establishing political connections?

N.N. Amorita, D. Agustia \& I. Harymawan

Integration of corporate social responsibility and resource based theory to create

and capture value

N. Nandang \& H. Mulyadi

Organizational behavior, leadership and human resources management

Superior performance model of human resources

T. Yuniarsih, Disman \& M.D. Sugiharto

The impact of fiscal decentralization on economic growth and manpower absorbed at districts/cities in South Kalimantan Province

Muzdalifah \& R. Purwono

Work-family conflict and satisfactions: A job demand-resources model perspective

J. Sulistiawan

Building employee engagement through transformational leadership, psychological empowerment and affective commitment

P. Yulianti \& N. Hamidah

The impact of transformational leadership, learning organization and job autonomy on creative self-efficacy

I. B. G. A. Permana \& W. Astiti

Enhancing commitment to organizational change initiative and performance outcomes N.A. Arina \& P. Yulianti

The influence of Perception of Usefulness (PoU) and Perceived Ease of Use (PEU) on the perception of information system performance

F. Sayekti \& L.E. Wijayanti

Knowledge sharing benefits: The contingency effects of environmental contexts

A. Qomariyah

The antecedents of entrepreneurial intentions in students of Airlangga university

(A study of student participants in WEBS in the faculty of economics and business)

P. Yulianti \& I. G.N.W.H. Saputra

Effect of proactive personality and Organizational Support for Career Development (OSCD) on career satisfaction and job performance

V. Octia \& D. Ratmawati

The effects of transformational and transactional leadership on work performance of middle-level leaders with organizational commitment as mediator: A study of state-owned company, Pelabuhan Indonesia III Inc.

A. Eliyana, S. Maarif \& R.J. Sunarsono 
Transformational leadership style, team performance and team job satisfaction:

Mediation by levels of cognitive trust and collective efficacy

P. Yulianti \& R. Sanjaya

The impact of self-efficacy and perceived organizational support on operational managers' readiness to change

H. Prima \& A. Eliyana

\section{Marketing management}

Factors affecting customer retention in a priority banking program

I.R. Aliyah, S. Soebandhi \& A. Baktiono

The impact of messages assertiveness on compliance with perceived importance as a moderation variable on the anti-cigarette campaign in Surabaya

Kristiningsih, R.S. Wuryaningrum \& A. Trimarjono

Demographic variables and environmentally friendly behavior in a developing country

T. Handriana

Antecedents and consequences of ongoing search information

D. T. Firmansyah \& D. Mardhiyah

Role of negative brand name perception and religiosity on brand attitude

S. Gunawan \& R.T. Ratnasari

The effects of good/bad news on consumer responses toward higher education

G.C. Premananto \& M.H. Hanafiah

Examining leadership style and advertising evaluation on employees'

customer focus

R.A. Aisyah \& N.A. Arina

The effect of airline sale promotion types on consumers' attitudes toward brand and purchase intentions

M. Kurniawati

The influence of celebgrams, e-WOM, and pictures on impulse buying

Hartini, Sri \& Uswatun

Value propositions of supermarkets

R. Rinawati

Empirical study of perceived quality information and perceived information security impact on online purchasing in Indonesia

L. Lisnawati, L.A. Wibowo \& P. Andi

Measuring religiosity and its effects on attitude and intention to wear a hijab:

Revalidating the scale

H.A. Wibowo \& M.R. Masitoh

\section{Management and economics education}

Communication skills of accountants and managers in Indonesia

Y.L. Rudianto \& A.R. Sridadi

Factors knowledge management and the work motivation of lecturers

Rino

The role of talent management in student performance in higher education

D. Purwaningsih

Strategy to build universities

P. Dewi Dirgantari, B. Widjajanta \& L. Lisnawati

Factors affecting the improvement of students' Grade Point Average (GPA)

A.B. Santoso, E.C.M. Simatupang \& R.H. Sofyandi 
Innovation, operations and supply chain management

Analysis of the small segment credit business process at Bank ABC Indonesia

A.C. Saifullah \& R.D. Kusumastuti

The identification of defects in rubber slipper production using the six sigma method

T.A. Auliandri \& M.A. Setiani

The design of service quality improvement in a library by using LibQUAL model and fishbone diagram

F. Wurjaningrum \& A. Kurniawan

The strategic role of Indonesia in Global Value Chains (GVC)

M.A. Esquivias, D. W. Sari \& R.D. Handoyo

N. Anridho

Efficiency and total-factor productivity in the manufacturing industry in

33 provinces of Indonesia

Muryani

Academic excellence and total quality supply chain management in higher education

I. Usman \& Windijarto

Financial management and accounting

The influence of usage accounting information on small medium enterprise's perception

S. Mintarti, D. M. Sari \& T. Fitriastuti

Determinants of banks' net interest margin in five South East Asian countries

M. Gitanadya \& R. Setiawan

The effect of monetary policy and macroeconomic variables on foreign portfolio investment in Indonesia

N.F. Anne \& R. Purwono

Internal factors, external factors, and bank liquidity in Indonesia

I.M. Sudana \& A.F. Akbar

The obstacles in developing Indonesia's sovereign sukuk

N. Laila, F.F. Hasib \& M. Anshori

The effect of trading volume changes on JKSE's market return

M. Madyan, S. Hasan \& D.F. Putri

The influence of the profitability indicator, capital and performing loans on the liquidity of the bank in the Indonesian stock exchange

O.V.B. Nainggolan

Corporate governance performance evaluation of banks operating in Indonesia

F. Budhijono

What drives finance pattern debt companies to pay dividends in Indonesia?

L. Gestanti \& G. Memarista

Diversification, firm value and government ownership

S. A. Usman \& C. Sulistyowati

Do operating costs, investment returns and claims have an effect on contributions?

D.F. Septiarini

S.R. Arifin \& Wisudanto

Different ways to solve the liquidity problem of Indonesian Islamic microfinance

I. Mawardi \& T. Widiastuti 


\section{Preface}

International Conferences provide an excellent opportunity to bring together academics from different countries and backgrounds for the purpose of presenting their research results, critically discussing methodology and findings and improving the quality of research and the impact of the research on society and science. Furthermore, conferences enable the scientific community to create new networks, to foster relationships and extend their visibility.

The 2nd Global Conference on Business Management and Entrepreneurship (GCBME) 2017 is an annual conference co-hosted by Department of Management, Faculty of Economics \& Business, Universitas Airlangga and Business Management Education Program, Faculty of Business and Economics Education, Universitas Pendidikan Indonesia. The theme of GCBME 2017 is increasing management relevance and competitiveness.

The theme inspired by the concern of Sumantra Ghoshal that bad management theories are destroying good management practices. Before that, the dichotomy between rigor and relevance is always becoming a hot topic in the management field. This conference aims to answer the following question: How might we accomplish a reconciliation of rigor (academic) and relevance (practitioner) standards to offer organizational competitiveness?

I expect this conference raises two important things in the discussion room and proceedings (based on Corley and Gioia, 2011): First, theories used in this conference should be problem driven-that is addressing a problem of direct, indirect, or long-linked relevance to practice, rather than narrowly addressing the (theoretical) "problem." Second, the fact that we are a profession (academia) studying another profession (management), therefore it needs balancing between theoretical contribution managerial implications. By doing that, I believe that our research and discussion in this conference could offer something useful for practitioners (thus increase its competitiveness) while at the same time contribute to the development of our management field.

I am looking forward to seeing you in GCBME in the near future.

With warmest regards,

Prof. Badri Munir Sukoco, $\mathrm{PhD}$

GC-BME 2017 Conference Chair 
Increasing Management Relevance and Competitiveness - Sukoco et al. (Eds) (C) 2018 Taylor \& Francis Group, London, ISBN 978-0-8153-7455-8

\section{Acknowledgements}

Badri Munir Sukoco, Universitas Airlangga, Indonesia Ratih Hurriyati, Universitas Pendidikan Indonesia Ade Gafar Abdullah, Universitas Pendidikan Indonesia Praptini Yulianti, Universitas Airlangga, Indonesia Muhammad Madyan, Universitas Airlangga, Indonesia Didi Sukyadi, Universitas Pendidikan Indonesia Wann-Yih Wu, Nanhua University, Taiwan John Nowland, Illinois State University, USA

Ikuro Yamamoto, Kinjo Gakuin University Nagoya, Japan

Jon Lovett, University of Leeds, UK

John Paul, Kedge Business School, France

Ranbir Malik Singh, Curtin University, Australia

Nobuhide Otomo, Kanazawa University, Japan

Mohamed Dahlan Ibrahim, Universiti Malaysia Kelantan, Malaysia

Dadang Kurnia, GIZ, Germany 


\section{Organizing committees}

\section{ADVISORS}

Prof. John Paul

Prof. Ranbir Malik Singh

Prof. Dr. Nobuhide Otomo

Prof. Dr. Mohamed Dahlan Ibrahim

Prof. Dr. Anis Eliyana

Prof. Dr. Muslich Anshari

Prof. Dr. Fendy Suhariadi

Prof. Dr. Sri Iswati

Prof. Dr. Bambang Tjahjadi

Prof. Dr. Nanang Fattah

Prof. Dr.Agus Rahayu

Prof. Dr. Tjutju Yuniarsih

Prof. Dr. Disman

Prof. Dr. Suryana

Prof. Dr. Eeng Ahman

Prof. Dr. Ratih Hurriyati

Prof. Ina Primiana

\section{CONFERENCE CHAIR}

Prof. Badri Munir Sukoco, Ph.D

\section{COMMITTEES}

Dr. Tanti Handriana

Rahmat Heru Setianto, SE, M.Sc.

Nidya Ayu Arina, SM, MSM.

Dr. Masmira Kurniawati

Made Gitanadya, SE, MSM.

Ratri Amelia Aisyah, SM, MSM.
Prof. Lincoln Arsyad

Prof. Gunawan Sumodiningrat

Dr. Phil Dadang Kurnia

Assoc. Prof. Arry Akhmad Arman

Assoc. Prof. Dwilarso

Assoc. Prof. Hardianto Iristidi

Assoc. Prof. Rachmawaty Wangsaputra

Assoc. Prof. Teungku Ezni Balkiah

Assoc. Prof. Ruslan Priyadi

Assoc. Prof. Sri Gunawan,

Assoc. Prof. Dr. Indrianawati Usman

Assoc. Prof. Yudi Aziz

Assoc. Prof. Lili Adiwibowo

Assoc. Prof. Vanessa Gaffar

Assoc. Prof. Chaerul Furqon

Vina Andriany MEd, PhD

Tutin Ariyanti, $\mathrm{PhD}$ 


\title{
Academic excellence and total quality supply chain management in higher education
}

\author{
I. Usman \& Windijarto \\ Management Department, Faculty of Economy and Business, Airlangga University, Indonesia
}

\begin{abstract}
The purpose of this study was to analyze the concept of supply chain quality management to support the achievement of academic excellence in a higher education study program. Empirical studies were carried out to identify good practice in the management of study programs in terms of the concepts of supply chain quality management. Currently, most universities have a quality management department, but the quality culture that raises academic performance in the organization does not yet exist. The method in this study involved empirical review of multiple case studies among those study programs at the forefront of performance achievement in higher education, specifically, those study programs which have already been awarded the highest grade by the Indonesian National Accreditation institution. The results of this study are expected to provide a model of total supply chain quality management for a study program to achieve academic excellence and enhanced performance.
\end{abstract}

Keywords: Total Quality Management, Supply Chain Management, Total Quality Supply Chain Management

\section{INTRODUCTION}

This research will explore how to develop supply chain quality management in order to create academic excellence. A new, well-integrated framework should be developed to facilitate the implementation of Supply Chain Management (SCM) and Total Quality Management (TQM). The traditional approach to TQM emphasizes specificationbased performance, while SCM tends to focus on time-based performance (Vanichchinchai \& Igel, 2009). The interesting thing in conceptualizing the education system as a supply chain is that a supply chain will generally involve several entities that are directly related to each other, both upstream and downstream (Mentzer et al., 2001). Educational services have the same process in terms of operating functions, for instance, transforming inputs into outputs (Slack et al., 2012). Services account for $70 \%$ of the workforce in advanced economies, including the government sector and education. Overall, this will exceed manufacturing and agribusiness industries (Economist, 2014).

Considering these circumstances, it is time that Supply Chain Quality Management (SCQM) theory and practice were further developed. It is understood that education produces well-educated human resources, but has this sector been implemented in the most effective way, given that the management of educational systems is becoming so complex (Mason, 2008; Snyder, 2013)? Rashid and Aslam (2012) state that, currently, most universities have a quality management department, but the quality culture that raises academic performance in the organization does not yet exist.

The results of this study will form a basic foundation for the development of studies in the area of strategic management, operations management and SCQM, both theoretical and practical. The practical benefit of this research will be in providing a new practical concept for the management of study programs designed to achieve academic excellence through the application of the Total Quality Supply Chain Management (TQSCM) concept.

\subsection{Conceptual background}

The definition of supply chain management has evolved as part of modern business management concepts and SCM can enhance an organization's capacity to achieve its strategic objectives. This means that supply chain concepts are very useful in support of the management practices of an organization. SCM activities can be described as having three components: supply chain configuration; supply chain relationship, and supply chain coordination (see Figure 1).

Supply chain configuration consists of strategic decisions and concerns the construction of all participant organizations in the chain, also referred to 


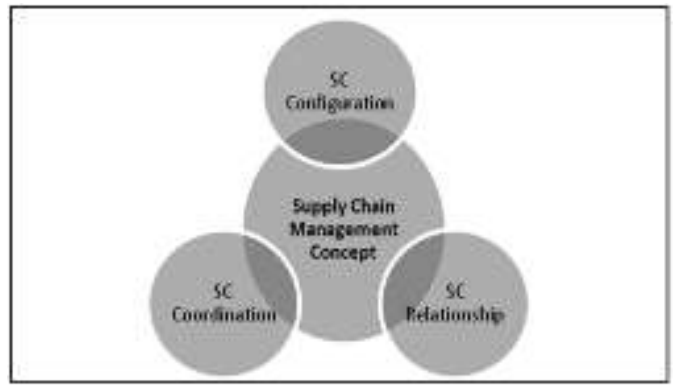

Figure 1. Supply Chain (SC) management conceptual model (Source:Storey, Emberson, Godsell, \& Harrison, 2006).

as supply chain architecture. Supply chain relationship concerns the relationships between organizations in the supply chain. In terms of level, decisions associated with supply chain relationships can be strategic or operational. Supply chain coordination deals with coordination between organizations in the supply chain. Decisions about supply chain coordination are operational in nature. The conceptual model (Figure 1) also illustrates the interrelationship with managerial decision-making within the organization, which includes strategic, tactical and operational decisions.

\subsection{Total quality supply chain management}

The development of university audit efforts to attain academic excellence is concerned with quality assurance activities. TQM is a management philosophy intended to drive cost reduction, creation of high-quality goods and services, customer satisfaction, employee empowerment and measurement. SCM strategy focuses on developing strategic alliances according to core competencies. In a new economic era, companies operate manufacturing or services by integrating corporate partnership activities along the value chain. The fundamental challenge in applying TQM all the way to the base of the value chain in supply chain networks is the development of programs and techniques that encourage diverse cultures among human resources to make continuous improvements in all areas that reflect the ambitions of the organization.

Total Quality Supply Chain Management (TQSCM) is a combination of SCM and TQM activities: SCM is a paradigm aimed at adjusting the system to the supply chain so as to create harmony in all processes, while quality improvement is pursued to achieve given levels of achievement or better. These SCM and TQM activities need to be integrated, as they are closely related; better quality cannot be achieved without supply chain integration, and continuous quality improvement efforts also result in integration among supply chain partners. Therefore, we need a framework to manage quality throughout the supply chain. Previous research has been undertaken by Robinson and Malhotra (2005), and Foster and Ogden (2008), while a study of TQM and SCM practices was conducted by Sila et al. (2006). The purpose of this study is to identify TQM and SCM practices that are often used in organizations. We also compare and illustrate the relationship between TQM and SCM, using a review of literature from published papers that adopt different types of organization.

\section{METHODOLOGY}

This research uses qualitative exploratory research, and a multi-case study approach. The research design has several levels of analysis to improve the accuracy and richness of the resulting theory (Cheng, 1997) Eisenhardt, 1989), and focuses on the management of study programs that have implemented TQM. The research was conducted on undergraduate study programs in Indonesia that have been rated " $\mathrm{A}$ " by the National Accreditation Board of Higher Education. Data were collected through face-to-face and telephone interviews, and emails to track the strategies used through the media and materials owned by existing study programs and external databases. Researchers also conducted pilot interviews with university quality control leaders, in relation to faculty and study programs. The data obtained were processed and analyzed to formulate a Total Quality Supply Chain Management (TQSCM) model.

\section{ANALYSIS AND RESULTS}

In critical terms, top-management commitment in SCM is referred to by different levels and terms, such as changing corporate culture, management support, participative management, and cooperation, but the underlying concept is the same in the case of both TQM and SCM. Moreover, TQM and SCM can only succeed in achieving improved performance in an organization with the continuous support of senior management and their efforts towards never-ending improvement in customer services and customer satisfaction. TQM and SCM both play an important role in improving the competitiveness of an organization (Sila et al., 2006). The development of global competition today makes the situation even more complex and difficult. Existing challenges include a focus on the supply chain to determine timely and targeted 
shipments for product delivery (Chin et al., 2004; Robinson \& Malhotra, 2005).

Although TQM and SCM are important for organizational performance, they are seldom studied simultaneously (Casadesus \& Castro, 2005; Robinson \& Malhotra, 2005). Some researchers (Vanichchinchai \& Igel, 2009, 2011) have also stated that, although SCM and TQM are important management systems for achieving competitive advantage, the success rate of implementations in organizations is not the same. SCM is the coordination and integration of all supply chain activities to make a process run smoothly, this is demonstrated through improved supply chain performance. The synergy between quality management and SCM leads to improved supply chain performance (Robinson \& Malhotra, 2005; Foster \& Ogden, 2008; Kuei et al., 2001).

Initially, the development of synergy between quality management and SCM occurred in the manufacturing sector, and the wholesale and retail industries. Utilization of such integration is still low in service industries. The education sector is similar to other service operations; it involves the process of changing inputs into outputs (Slack et al., 2012). Habib and Jungthirapanich (2009) conducted research on supply chain education in universities. Through exploratory research, a new dimension for education management is provided, revealing the importance of the supply chain in contributing to the success of university operations. Contributions include human resources and research contributions to end customers, that is, communities. Effective education depends on the knowledge, experience and ethics of its personnel. (Sarrico \& Rosa, 2016) conducted a study to introduce a supply chain quality management (SCQM) concept into education. This study found that education is an SCM system. SCQM in education presents a challenge, with respect to trust for information sharing, integration and leadership. Nevertheless, this study also found some good practices in a more systematic SCQM implementation. Based on the analysis of several study programs, we conclude that SCM serves to balance all parties involved in meeting the demands of consumers, ranging from those upstream to those downstream. The Supply Chain Operations Reference (SCOR) model, developed by the Supply Chain Council (TX, USA), can be implemented in the operational academic process to obtain high-quality graduates and research.

In Indonesia, study programs that obtain an "A" grade from the National Accreditation Board of Higher Education have generally run quality assurance. Based on observations of some of the "A"-rated management majors, all have performed quality assurance, yet no study program has taken advantage of the SCM concept in its design strategy
Table 1. TQM and SCM critical practices.

\begin{tabular}{|c|c|}
\hline Critical & ctice \\
\hline SCOR 1 & del (SCM practice) \\
\hline Plan & $\begin{array}{l}\text { The coordination plan of units related to the } \\
\text { study programs }\end{array}$ \\
\hline Source & $\begin{array}{l}\text { Identification of the source qualification to } \\
\text { support the academic operation of the } \\
\text { study programs (incoming student, } \\
\text { facilities, lecturer, etc.) }\end{array}$ \\
\hline Make & $\begin{array}{l}\text { Operational academic process of study } \\
\text { program }\end{array}$ \\
\hline Deliver & Relevance of graduate \\
\hline Return & Organizing feedback from stakeholders \\
\hline PDCA & le (TQM practice) \\
\hline Plan & $\begin{array}{l}\text { How the quality assurance (QA) activity is } \\
\text { planned and practiced }\end{array}$ \\
\hline Do & How the QA is organized \\
\hline Check & QA activities processed \\
\hline Act & $\begin{array}{l}\text { Assessment process of teaching learning and } \\
\text { research activities }\end{array}$ \\
\hline & Continuity in assessment processes \\
\hline & $\begin{array}{l}\text { Consistency and reliability of the QA } \\
\text { programs }\end{array}$ \\
\hline & $\begin{array}{l}\text { Converting/transforming feedback into } \\
\text { program improvements }\end{array}$ \\
\hline
\end{tabular}

to achieve its performance. Based on interviews, observations and references relating to the higher education value chain, SCM critical practices based on the SCOR model and TQM critical practices based on the Plan-Do-Check-Act (PDCA) cycle are applicable to study programs.

The result of semi-structured interviews with heads of study programs, lecturers, administrative staff and quality assurance managers resulted in a TQSCM design. The integration of both TQM and TQM in study program, call TQSCM design indicate that implementation of SCM and quality management practice integration will improve the achievements of study program's performance.

\section{REFERENCES}

Casadesus, M. \& Castro, R. (2005). How improving quality improves supply chain management: Empirical study. TQM Magazine, 17(4), 345-357.

Chin, K.S., Tummala, V.M.R., Leung, J.P.F. \& Tang, X. (2004). A study on supply chain management practices: The Hong Kong manufacturing perspective. International Journal of Physical Distribution \& Logistics Management, 34(6), 505-524.

Cheng, Y.C.(1997). Quality assurance in Education "A framework for dimensions of quality in higher education", Quality Assurance in Quality assurance in education: internal, interface, and future. Quality Assurance in Education Iss Quality Assurance in 
Education Iss Education, 11(22), 202-213. Retrieved from http://dx.doi.org/10.1108/09684880310501386.

Economist. (2014, January 18). The onrushing wave. The Economist. Retrieved from https://www.economist. com/news/briefing/21594264-previous-technologicalinnovation-has-always-delivered-more-long-runemployment-not-less.

Eisenhardt, K.M. (1989). Building theories from case study research. Academy of Management Review, 14(4), 532-550.

Foster, S.T., Jr. \& Ogden, J. (2008). On differences in how operations and supply chain managers approach quality management. International Journal of Production Research, 46(2), 6945-6961.

Gunasekaran, A. \& McGaughey, R.E. (2003). TQM in supply chain management. TQM Magazine, 15(6), 361-363.

Habib, M.M. \& Jungthirapanich, C. (2009). Research framework of education supply chain, research supply chain and educational management for the universities. International Journal of the Computer, the Internet and Management, 17(SP1), 24.1-24.8.

Kuei, C.H., Madu, N.C. \& Lin. C. (2001). The relationship between supply chain quality management practices and organizational performance. International Journal of Quality \& Reliability Management, 18(8), 864-872.

Lau, A.K.W. (2007). Educational supply chain management: A case study. On The Horizon, 15(1), 15-27.

Li, S., Ragu-Nathan, B., Ragu-Nathan, T.S. \& Rao, S.S. (2006). The impact of supply chain management practices on competitive advantage and organizational performance. Omega, 34, 107-124.

Mason, M. (Ed.). (2008). Complexity theory and the philosophy of education. Chichester, UK: Wiley-Blackwell.

Mentzer, J.T., DeWitt, W., Keebler, J.S., Min, S., Nix, N.W., Smith, N.C.D. \& Zacharia, Z.G. (2001). Defining supply chain management. Journal of Business Logistics, 22(2), 1-25.

Rashid, K. \& Aslam, M.M.H. (2012). Business excellence through total supply chain quality management. Asian Journal on Quality, 13(3), 309-324.
Robinson, C.J. \& Malhotra, M.K. (2005). Defining the concept of supply chain quality management and its relevance to academic and industrial practice. International Journal of Production Economics, 96, 315-337.

Sarrico, C.S. \& Rosa, M.J. (2016). Supply chain management in education. International Journal of Quality \& Reliability Management, 33(4), 499-517.

Sila, I., Ebrahimpour, M. \& Birkholz. C. (2006). Quality in supply chains: An empirical analysis. Supply Chain Management: An International Journal, 1(6), 491-502.

Slack, N., Brandon-Jones, A., Johnston, R. \& Betts, A. (2012). Operations and process management. Harlow, UK: Pearson.

Snyder, S. (2013). The simple, the complicated, and the complex: Educational reform through the lens of complexity theory. Paris, France: OECD.

Storey, J., Emberson, C., Godsell, J., \& Harrison, A. (2006). International Journal of Operations \& Production Management Supply chain management: theory, practice and future challenges "Supply chain management practices in toy supply chains", Supply Chain Management: An. International Journal of Operations \& Production Management An International Journal Iss International Journal, 26(5), 754-774. Retrieved from http://dx.doi.org/10.1108/01443570610672220.

Vanichchinchai, A. (2012). The relationship between employee involvement, partnership management and supply performance: Findings from a developing country. International Journal of Productivity and Performance Management, 61(2), 157-172.

Vanichchinchai, A. \& Igel, B. (2009). Total quality management and supply chain management: Similarities and differences. TQM Journal, 21(3), 249-260.

Vanichchinchai, A. \& Igel, B. (2011). The impact of total quality management on supply chain management and firm's supply performance. International Journal of Production Research, 49(11), 3405-3424. 